\title{
WINE MANAGEMENT AND MULTIPLIER EFFECTS ON LOCAL ECONOMIES
}

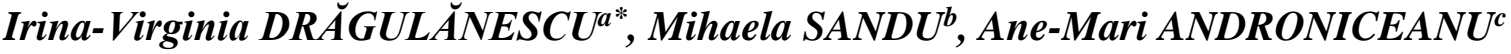 \\ ${ }^{a, b}$ University of Bucharest, Romania \\ ${ }^{c}$ Bucharest University of Economic Studies, Romania
}

\begin{abstract}
The soft economy is the model in which at local level, the enterprises are based on alliances between knowledge, new technologies, tradition and the competitiveness which stimulate the training, research, social cohesion and positive relationships with communities. When the "wine product" becomes a resource can be develop economic opportunities for companies in terms of sales and amplification of the local market. The wine can be considered an expression of the territory and environment. So, the wine tourism is a way to spend the holidays, so to become a trend. The expectations of the wine companies in Italy are clear: to make known the territory, the products and their company; to offer the consumer a quality experience through winery tours, guided tastings and sales of their products. The establishment of the wine routes represent a unique opportunity for producers and operators to present, propose, promote and launch their products and services. The wine routes have potentiality to be expressed in order to enhance the food and wine culture, territories and the environment with important multiplier effects on local economies. The purpose of our study is to understand the motivations of the individual actions of wine producers for the construction of a mathematical model of global evaluation of the mechanism through which micro behaviors can be translated into macro structures such as wine routes, also, according to our reworking of Von Tünen regional land use model.
\end{abstract}

KEYWORDS: local economy, multiplier effect, Von Tünen Model, wine management, wine route

\section{INTRODUCTION}

During the last few years, numerous UE countries are facing hard phenomena as depopulation of rural areas, desertification, etc. To overcome these difficulties have already been launched general and local policy intervention to support the people, thus it was undertaken a new phase of development to address these major problems. This was achieved by maintaining an adequate network of services and activities which is a sine qua non for economic revitalization of rural areas. The entrepreneurial and agricultural development, through incentives and new opportunities (mainly destined to the small and very small business), may, therefore, favoring those virtuous economic circles, able to carry out environmental benefits primarily by applying technological innovation. Moreover, through these initiatives, will be possible to recover many forms of craft working experience that historically characterized the territories. Consequently, to the current economic and trade dynamics influenced by globalisation, it was necessary to design policies aimed to safeguard the typical products from falsification phenomenon. Indeed, for a long time, unfair competition through the use of names and/or images improperly with regard to products that don't belong to that territory, produced negative effects, on the one hand, the fraud of consumers, especially the foreign ones, and on the other hand de facto the erosion of the market with heavy repercussions on the local economies and also national economy. Proper to regulate and promote the local production activities, were introduced new

\footnotetext{
* Corresponding author. E-mail address: irina.dragulanescu@faa.unibuc.ro
} 
measures and tools that links inseparably the product to the territory (promotion and/or creation of brands, and investments to sustain local and regional products, agricultural quality and forestry), with positive effects on the local economy. The agricultural and food products - above all those that boast the denominations of origin and protected certification, as registered designation of origin (DOC), designation of origin and guaranteed (DOCG), protected designations of origin (PDO) and Protected Geographical Indication (PGI) - today represent a logistic closely related reference for identifying the territorial areas of undisputed cultural value, historical, artistic and socio-economic relevance.

It emerges, therefore, a multidimensional and innovative multifunctional interpretation of the agricultural activity, which combine old and new applications of intervention in a continuous process of evolution and adaptation to the necessities of modern society. It follows that the development of rural areas is essentially a collective creation in which many different actors and production units concur, entering in relations between them with in order to exchange tangible and intangible assets. The more, these relationships take on the structure of relationships of intersectoral and territorial integration, the more the process of spreading and diversification of economic activities in the area grows. In this way, is originated a socio-economic and territorial system, in which the recovery and maintenance of cultural roots and local specificity activate the diversification of agricultural and food products as a vehicle for the promotion of the territorial supply and, together, contribute to orienting the tourist demand and food and wine consumption.

Therefore, the endogenous development of rural areas on one hand and the increasing interest for agribusiness tourism on another, evidences the role that the wine sector plays for tourist development within the areas of strong wine-growing vocation and producing.

In this paper our purpose is to demonstrate that a good management at a territorial level can contribute to limit to limit the exodus of the local population and help to rediscover the rural and landscape environments by enhancing the territory under the cultural and local traditions aspect. Wine routes with an appropriate management represent a direct economic tool for local economies to achieve economic, social and environmental objectives Wine routes with an appropriate management represent a direct economic tool for local economies to achieve economic, social and environmental objectives by enhancing the activities and the traditional rural world. By encouraging the development of innovative processes of farms it can be better respond to the needs of the consumer, who is increasingly demanding. For these objectives we developed a mathematical model, and we calculated the multiplier effect of the institution of the wine route by finding the connections with other economic sectors and the effects on the development of local economies.

\section{METHODOLOGY}

The purpose of our study was to gain the necessary knowleges regarding the individual actions and motivations of wine producers to be transferate into a global model and the mechanism by which micro behaviors translates to macro structures as wine routes. Thus, we developed the SWOT analysis concerning the wine routes in Italy. Then, we elaborate a mathematical model of development achievable in a "wine route" to calculate the multiplier effect on local economies. By explicitly modeling micro-scale, or individual level actions, we expect that a few well-understood economic forces will combine with spatial location to collectively produce a global pattern. We calculated, to exemplify the importance of interaction between the various producers, the wealth of the route obtained after one producing/selling cycle in a food and wine route, with four producers dealing in the sectors of wine, food and handicrafts, refreshment, accommodation. The aspects were confirmed, also, by our reworking of Von Tünen agrarian land use model. Based on our results it is necessary to develop a network of stakeholders to respond to the growing demand for food and wine tourism, valorising the territory with positive effects on the local economies. 


\section{THE WINE SECTOR IN ITALY}

The wine sector is a pillar of the made in Italy and of the agro-food system. Italy is the world's leading wine producer in quantity, the second largest exporter of wines and sparkling wines in value (after France), the leading exporter of vermouth, liqueurs and cordials, vinegars and substitutes grapes. In 2019, the Italian National Statistics Institute item "grape wines", including the still wines and sparkling wines, recorded an export of 6.4 billion euro, imports for only 335 million and consequently a trade surplus with other foreign countries 6.1 billion which makes this sector one of the significant components of the Italian balance of payments.

According to a study by Unicredit (2019), in the Italian wine sector there are about 2,000 industrial enterprises and a turnover of over 11 billion Euros, about 8\% of the national turnover of the Food \& Beverage sector. With 524 certified products, Italy holds the world record of certified wines by geographical indications (Protected Designation of Origin and Protected Geographical Indication). One wine in 3 certified in Europe is produced in Italy (France is second with 435 wines), 68\% of the wine produced in Italy in 2018 was PDO or PGI. The Unicredit (2019) analysis highlights that in the last decade Italian wine exports have focused more and more on the quality, with a rapid growth of sales, $+5.2 \%$ average per year in the 2007/2018 period compared to volumes exported, which remained almost unchanged (+ $0.3 \%$ in the same period). The United States remains the leading market for Italian wines (1.5 billion euro in 2019, ISTAT data), followed by Germany (1.06 billion) and the UK (771 million), country, the latter, in which Prosecco has had enormous success in recent years. Other important markets for Italian wines and sparkling wines are: Switzerland (381 million euros, also in 2019), Canada (342 million), France (203 million), Japan (183 million), Sweden (178 million), the Netherlands (167 million), Denmark (141 million) and China (134 million).

\section{THE RELATIONSHIP BETWEEN WINE, TERRITORY AND TOURISM}

The current evolution of the territorial logic of development is expressed in the political will to proceed with the "districting” of rural production systems. The agricultural and agro-industrial enterprise, due to its link with the territory, would seem suitable for integrating into the district logic but suffers a great fragility as a rarely autonomous entity that entrusts an important part of its validity to external intervention and that hardly accepts, to participate in organizational forms within functional systems. The phenomenon of "roads", therefore, is a form of concerted initiative of valorisation between operators and institutions that cross the territorial entity with a common thread that integrates the wine product offering with that of the territory as a whole. The route takes on its most important significance in relation to the growing tourist flows, as a tool capable of attracting the territory and conveying the multiple aspects of the experience of contact with local cultures. The wine receives from the route fame and promotion, and this in turn provides his services. However, the whole system is affected by the region's backwardness in structuring a high-level tourist offer that, respecting the identity of the territory, is capable of attracting the flows of international tourism that most intensely produce the phenomenon of economic activation.

The evolution of the awareness of the most qualified winemakers and wine entrepreneurs, regarding the importance of achieving qualitative rather than quantitative primates, through the improvement of all phases of the production process (through "Quality Systems" and "Total Quality

Management”), investments aimed at the acquisition of process, product and management innovations and adequate promotion of the image of companies and territories of origin.

In the new economic vision, the rural areas are valorised through integrated supply management of agricultural and food products offered directly or indirectly to consumers, increasing the participation of agricultural companies to provide services related to leisure, and in particular, to tourism activities contributing also to "design" the agrarian landscape in the optical of multifunctional role (Idda et al., 2002). The EU is the world's largest wine producer. Between 2014 and 2018 the annual average 
production was 167 million hectoliters. It represents $45 \%$ of the world's wine-growing areas, $65 \%$ of production, $60 \%$ of world consumption and $70 \%$ of exports.

The development focuses, in particular, on some strategic ties between the typical products, wine tourism, the rural area and the wine routes. The wine tourism supply should be considered in terms of localization of its resources and within the framework of anthropic, environmental, social and economic characteristics. In particular, these salient identifying elements of a local territorial typicality represent a strength of the territories, favoring the diversification of tourism supply in respect with other countries at wine tradition (fig. 1).

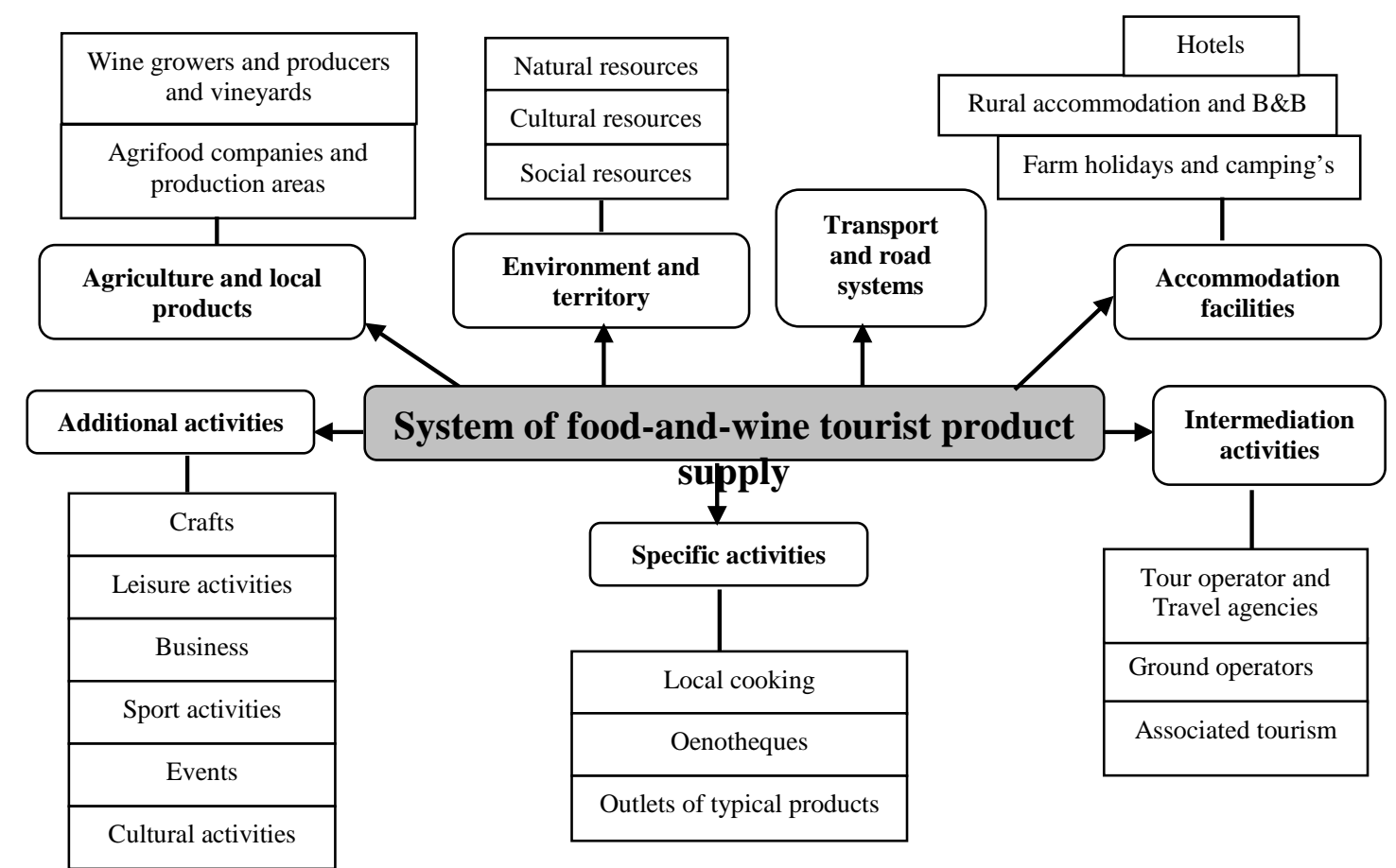

Figure 1. The system of food-and-wine tourist product supply

Source: our elaboration

From the relationship between agriculture and tourism derive important economic effects that are the consequence of tourism expenditure realized in the territory. These positive effects that affect both the production and the income and jobs can be direct (when involved without intermediation the local industry, as for example, for the purchase of local products at producers, in the "farmer market" or farms "pick your own"), and indirect (when spending reaches the agriculture sector through the channels of marketing and/or processing and sell to a third party, as in the case of consumption at the Food-Beverage industry and purchase at food distribution points). Therefore, the Wine Roads are a form of specialized tourist offer, which seeks to interpret and satisfy the new needs of the so-called "Tourists travellers", responding to an increasingly segmented tourist demand, with a model that represents an important development opportunity for wineries (because it produces supplementary and alternative income to the usual main activities), proposing at the

same time, as the main objectives, the enhancement, use and conservation of heritage, activities and rural "diversity". From a logistical point of view, the Wine Routes were created with the aim of connecting all the resources present in places and territories with a high wine-growing vocation, such as tourist itineraries along which vineyards, cellars of farms, wine bars, museums of grape and wine, information and reception centers, companies specialized in typical and quality productions, tourist accommodation facilities, natural, cultural and environmental values, etc. From an economic point of view, the road can be represented by a market, with actors on the demand side and the supply side. The actors on the demand side are tourists who travel along paths, associating experiences with 
emotions and multisensory discoveries; on the supply side, on the other hand, the reference figures are made up of those who live and work along that path, and are interested in involving tourists in new experiences as well as weaving relationships with other players in the wine tourism system in order to expand its potential: wineries, wine bars, agritourism companies, restaurants, travel agencies, artisan companies, but also local and regional institutions, research centers, cultural associations, etc.

\section{TOWARDS OENOLOGICAL TOURISM IN EUROPE}

The new vision of the relationship between local and global, between city and countryside, between developed and marginal areas defines an "European model" of agriculture and rural development (fig. 2). This approach of modern ruralism has generated a review from the communitarian organisms by designing and adoption of appropriate strategies. From this perspective, the rural territory represents the whole of resources and systems, where are living together and operating mature and innovative productive forms, and also typical and traditional, acting in concert with local communities respecting the proper values (traditional, cultural, etc.). Therefore, the modern rural development process is characterized by a change that, by preserving traditions, aims to improve the quality of life of rural communities through sustainable, endogenous and local renewal actions and adequate management aimed at strengthening and increasing local economies.

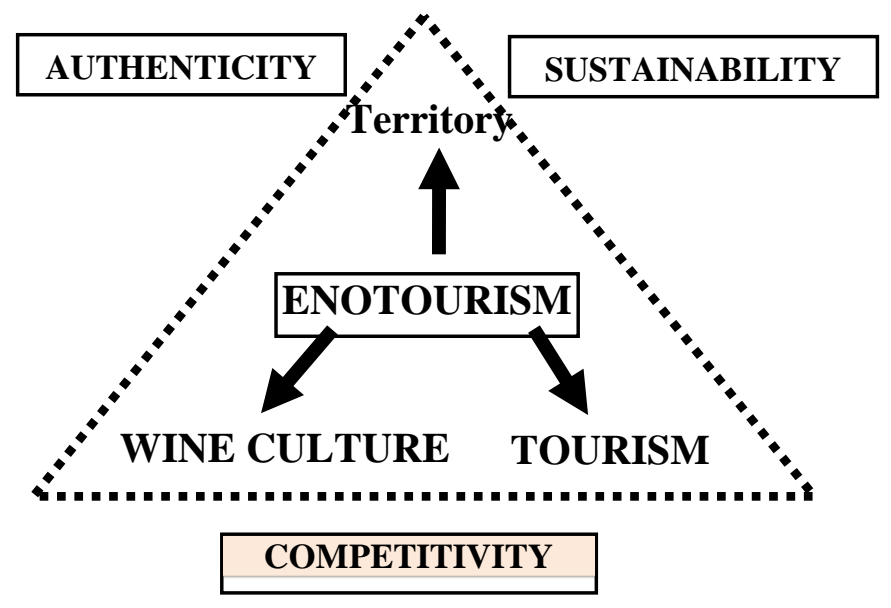

Figure 2. The fundamentals of European enotourism

Source: our elaboration

This aspect is realized in a logic of self-development by simultaneously respecting the autonomy and interdependency of individual levels of modern economy, within a global and multidimensional economic system. Moreover, based on the cooperation capacity of local companies, emerges as the territory is a reality on which is able to realize development hypothesis (endogenous actions), valuing the endogenous resources (agriculture, artistic patrimony, historic centres, natural environment, etc.) and integrating them with appropriate exogenous resources (economic, environmental and social policies, direct investment, etc.). The rurality, has always been synonymous of underdevelopment, in this new approach becomes a resource of high economic value, providing specific advantages to the EU (in terms of competitiveness) compared to other economic systems with limited rural reality. In this optic, the possible rural development through the adequate management of wine routes can play an important role. The quality of a wine is measured also by the quality of the territory on which it is produced: not only environmental, but also those of the traditions of secular culture, of making and knowledge. This cultural and productive model develops along wine-growing and producing/food and wine tourist district. The "Wine Routs" represent an 
experience under progressive consolidation, which is viewed with increasing attention by European institutions and big wine producers' countries. In fact, there are many areas in the world where is developing a successful relationship territory - wine - tourisms.

\subsection{Wine Routs in Italy}

In Italy, the strategic importance of wine growing and producing industry has gradually grown over the last years. Under the normative aspect, in Italy, almost of interventions regarding the agriculture and rural development is regulated and managed by the Regions, as it is in Spain and Germany, obviously within the limits of communitarian regulations for the implementation of which the Italian State has merely a coordination activity. Specifically, the matter of wine roads is based on the Law n. 268 of 27 July 1999, Regulation of wine routs. It is a general policy which has as its principal objective the valorization of the territories with wine-growing and producing vocation through the establishment of wine roads, with particularly regard to producing of Controlled Designation of Origin (DOC) and Guaranteed Controlled Designation of Origin (DOCG) wines.

Despite the expansion of these years, the $15^{\text {th }}$ National Report on Wine Tourism in Italy (2019) also underline, that the great part of the potentialities remains unexpressed. In fact, even if $97 \%$ of roads have a website and $90 \%$ organize events, in $49 \%$ of cases are missing, however, professionals necessary to adequately explain the characteristics and peculiarities of wine supply. Table 1 summarizes the most important information on the supply of food and wine tourism in Italy.

Table 1: The key components of wine tourism supply in Italy

\begin{tabular}{|c|c|c|c|}
\hline No & Components of Wine Tourism & & Numbers \\
\hline \multirow{4}{*}{1} & \multirow{4}{*}{ Total "Wine Roads" } & \multirow{4}{*}{$\begin{array}{l}150 \\
\text { of } \\
\text { which }\end{array}$} & - well organized (15\%) \\
\hline & & & - towards good organization (6\%) \\
\hline & & & - in the start-up phase (30\%) \\
\hline & & & - the remaining non-operating \\
\hline 2 & Differently existing roads & \multicolumn{2}{|r|}{ 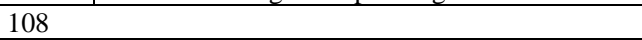 } \\
\hline 3 & Roads really operative & \multicolumn{2}{|l|}{60} \\
\hline 4 & Localities (smaller towns) crossed by the wine roads & \multicolumn{2}{|l|}{1.450} \\
\hline 5 & Wineries opening their doors to the public & \multicolumn{2}{|l|}{21.000} \\
\hline 6 & "Wine Towns" & \multicolumn{2}{|l|}{553} \\
\hline 7 & $\begin{array}{l}\text { Wines Controlled and Guaranteed Designation of Origin (DOCG), } \\
\text { Controlled Designation of Origin (DOC), Typical Geographical } \\
\text { Indication (IGT) }\end{array}$ & \multicolumn{2}{|l|}{524} \\
\hline \multirow{3}{*}{8} & \multirow{3}{*}{$\begin{array}{l}\text { Italian Protected Designation of Origin (PDO), Protected Geographical } \\
\text { Indication (PGI) according EU Regulation n. 1151/2012 of the European } \\
\text { Parliament and of the Council of } 21 \text { November } 2012 \text { (list updated to } 27 \\
\text { July 2020) }\end{array}$} & \multirow{3}{*}{$\begin{array}{l}305 \\
\text { of } \\
\text { which }\end{array}$} & $\begin{array}{l}\text { - } 168 \text { local products certified: PDO - Protected } \\
\text { Designation of Origin (italian DOP) }\end{array}$ \\
\hline & & & $\begin{array}{l}\text { - } 134 \text { Italian PGIs or italian IGP (Protected } \\
\text { Geographical Indication) }\end{array}$ \\
\hline & & & $\begin{array}{l}\text { - } 3 \text { Traditional Specialty Guaranteed (TSG): } \\
\text { traditional amatriciana, mozzarella and pizza }\end{array}$ \\
\hline 9 & Typical agricultural and food products recognized & \multicolumn{2}{|c|}{ more than $\mathbf{3 , 5 0 0}$} \\
\hline 10 & $\begin{array}{l}\text { Wine growers and producers within the "Wine roads" and listed by } \\
\text { tourist guide }\end{array}$ & \multicolumn{2}{|l|}{3.313} \\
\hline 11 & Restaurants along the "Wine roads" listed by tourist guide & \multicolumn{2}{|l|}{4.133} \\
\hline
\end{tabular}

Source: our elaboration on ISTAT data, different years

Despite the evident fragmentation (due to the excessive number of roads), the lovers who visit these roads have a remarkable expenditure capacity. Wine tourists are willing to spend to have a quality wine tourism experience. The economic effects on the territory are considerable, in fact, for 1 euro spent in the wine cellar within the territory are generated other 4 euros. Also, there is a greater attention to the new facilities formulas (different rural tourism forms, B\&B, resorts, etc) and to agricultural and food - productions of quality. The report shows that wine tourists have given very good ratings to the territories (7.18, on average), for the overall wine tourist offer (including activities wineries, restaurateurs, etc.). Wine tourists account for $26.9 \%$ of the turnover of wineries and $36 \%$ of restaurateurs, hoteliers and producers of typical products. The report underlines that the quality of infrastructures connecting the various territories is generally considered unsatisfactory (5.4), a low 
rating of 5.8 have gained the routes of wine and flavors because of not well management, as only 2 out of 3 municipalities participate to the initiative. In table 2 are listed the wine routes region by region. Tuscany and Sicily are the most attractive wine tourist region in Italy, getting almost half of global preferences (48.41\%), followed by Veneto, Emilia Romagna, Puglia, Lazio and Lombardy.

Table 2: Wine Roads in Italy

\begin{tabular}{|c|c|c|c|c|}
\hline REGION & Wine Routs & DOCG wines & DOC wines & IGT wines \\
\hline Abruzzi & 6 & 1 & 8 & 8 \\
\hline Basilicata & 4 & 1 & 4 & 1 \\
\hline Calabria & 6 & 0 & 9 & 10 \\
\hline Campania & 10 & 4 & 15 & 10 \\
\hline Emilia Romagna & 13 & 2 & 18 & 9 \\
\hline Friuli Venetia Giulia & 7 & 4 & 10 & 3 \\
\hline Lazio & 9 & 3 & 27 & 6 \\
\hline Liguria & 1 & 0 & 8 & 4 \\
\hline Lombardy & 9 & 5 & 22 & 15 \\
\hline Marche & 6 & 5 & 15 & 1 \\
\hline Molise & 1 & 0 & 4 & 2 \\
\hline Piedmont & 7 & 16 & 42 & 0 \\
\hline Puglia & 11 & 4 & 29 & 6 \\
\hline Sardinia & 8 & 1 & 17 & 15 \\
\hline Sicily & 17 & 1 & 23 & 7 \\
\hline Tuscany & 17 & 11 & 41 & 6 \\
\hline Trentino Alto Adige & 5 & 0 & 8 & 4 \\
\hline Umbria & 5 & 2 & 13 & 6 \\
\hline Valle D’Aosta & 5 & 0 & 1 & 0 \\
\hline Veneto & 16 & 14 & 28 & 10 \\
\hline TOTAL & 163 & 74 & 342 & 123 \\
\hline
\end{tabular}

Source: our elaboration on data: http://www.assovini.it/italia

However, despite the numerically positive results, requires a careful assessment of the phenomenon of tracing of typical and tradition products in order to limit the trend of excessive growth of the number of "Wine and Dine Routes", by strengthening the culture of marketing and the care of customer. The length of travel varies from a weekend to a week and motivation food and wine alongside the discovery of the territory and its cultural, artistic and naturalistic resources. 
Thanks to the multiplicity of values assumed, wine and food tourism can be considered a form of cultural tourism, contributing to the conservation and development of agricultural, wine growing and producing territories. This niche tourism allows the knowledge of the places, people and typical products. In most of the Wine Roads the offer is segmented into territorial sub-itineraries: the average duration of the itineraries is 4.1 days per road. The wineries that have opened to the public have an increase of $20 \%$ in turnover by selling directly to tourists and about $96 \%$ of wine tourists return home with a small supply of bottles after visiting a "Road".

Then, in table 3, we developed the SWOT analysis concerning the wine routes in Italy.

Table 3: SWOT analysis of the Italian Wine Routes

\begin{tabular}{|c|c|}
\hline WE & STRENGTHS \\
\hline $\begin{array}{l}\text { - underutilization of the structure } \\
\text { - small size of the enterprise } \\
\text { - low incidence of intermediation } \\
\text { - insufficient integration with other tourist } \\
\text { supply } \\
\text { - reduced adaptability of target } \\
\text { - static character of green tourism } \\
\text { - volatility of the market for its heavy } \\
\text { dependence on foreign }\end{array}$ & $\begin{array}{l}\text { - specific supply } \\
\text { - well-defined target } \\
\text { - considerable use of Internet } \\
\text { - promotion abroad } \\
\text { - positive perception by the tourist } \\
\text { - additional attractions (food and wine, natural and } \\
\text { cultural heritage, traditions) }\end{array}$ \\
\hline THREA & \\
\hline $\begin{array}{l}\text { - inability to contrast the last-minute } \\
\text { offensive } \\
\text { - circumscribe the wine tourism within the } \\
\text { nature tourism } \\
\text { - exclusive use of the farm tourism model } \\
\text { - exclusion from TO catalogues } \\
\text { - exclusive dependency on "auto-generated" } \\
\text { tourism demand } \\
\text { - difficulty to program the enterprise } \\
\text { - heavy decrease of the incoming }\end{array}$ & $\begin{array}{l}\text { - increment of the intermediation through } \\
\text { consortium structures } \\
\text { - widening of the target: extend the supply to } \\
\text { groups and adopt wine } \\
\text { - tourism innovation in order to capture shares also } \\
\text { in the business segment } \\
\text { - valorization of the food and wine } \\
\text { - enhancement of particular accommodation } \\
\text { specificities } \\
\text { - revaluation of the rural areas } \\
\text { - increase educational / experiential tourism }\end{array}$ \\
\hline \multicolumn{2}{|c|}{ Opportunities and threats of wine tourism at wine growing and producing territories } \\
\hline \multicolumn{2}{|c|}{$\begin{array}{l}\text { - tourist carrying capacity; lifecycle of wine tourism destination; configuration of the "tourist } \\
\text { degradation", social sustainability; farm tourism, rural tourism, widespread hotel and/or } \\
\text { hospitality widespread in the old village, B\&B, etc }\end{array}$} \\
\hline
\end{tabular}

Source: our elaboration

\section{TRAVELING TO THE TERRITORY TO REACH THE PRODUCT}

Enotourism can become the tourism of the restart, because it is very popular with young people, lovers of Italian wine and food and best meets the criteria of post-Covid-19 travel. In fact, enotourism is a tourism of proximity and economically sustainable, which allows experiences for a few or small groups of half a day or a weekend. It can be practiced outdoors, with visits to the vineyard and cellar, but also can be integrated with other territorial offer, as restaurants and accommodation facilities, 
cultural heritage and local gastronomic products. In this context was created The new enotourism project, a platform that aims to organize and train "Consortium for the Protection of Wines" (Gori \& Alampi Sottini, 2014) to seize this opportunity, also taking into account constraints that are placed to the cellars.

Wine and certified quality products (DOP, DOC and DOCG) are fundamental for food and wine tourism, which at the international level is one of the drivers of tourism demand, with an almost triple growth compared to traditional tourism sectors. Food and wine tourism and especially enotourism are the synthesis between production and territory. So, in order to develop them, it is essential to promote the narrative of the entire supply chain, offering an increasingly aware tourist a structured network of information and experiences.

The $16^{\text {th }}$ Italian Food and Wine Tourism Report (2020) shows that Millennials (born between 1981 and 1996) have been the main drivers of the growth of food and wine tourism worldwide. In the "near future" the tourists to refer to will be those of Generation Z, the superfoodie ones born after 1997, strongly interested in the food and wine holiday as a unique and memorable experience. The main consumer is documented mainly digitally, $80 \%$ of them visited a destination or participated in themed experience as a result of information from videos, posts, and reviews posted on the net.

At the beginning of 2020 is born the platform 'Il Nuovo Enoturismo', a project which aims to support, Producers Protection Consortia and Territorial Promotion Entities in the best and rapidly application of the determinations of the Decree and their updating, both with training tools and with communication solutions (DECREE n. 2779 of 12/03/2019 - Guidelines and guidelines regarding the minimum quality requirements and standards for the exercise of the enotourism activity).

The project started with the 3 Webinar cycle "The new wine tourism: instructions for use", involving experts from different topics, from the Italian and international scenario to the new wine tourism trends; from attention to Covid-19 security to administrative procedures and hospitality in the vineyard and in the cellar, up to the connections with the territory. Therefore, communication by paying attention to the different off- and online tools, the promotion and sale of the wine tourism experience in networks with tour operators, integration with e-commerce.

If in 'normal' times the wine experience was lived mainly in the cellar, now in time of covid-19 it will be increasingly experienced even in the vineyard where distancing can be respected.

Edutainment - with didactic harvest, picnic among the rows and open-air tastings that also involve the agri-food excellence of the area - is an increasingly important aspect of the new wine tourism offer: a simple and empathic, playful and educational, sustainable experience.

\section{MULTIPLIER EFFECT OF THE WINE ROUTE ON LOCAL ECONOMY}

The construction of a mathematical model of development achievable in a "wine route" starts by doing the description of the economic system: Wine Route. By explicitly modeling micro-scale, or individual level actions, we expect that a few well-understood economic forces will combine with spatial location to collectively produce a global pattern.

It is defined $S$ as a production route, that is a finite number of producers $S=\left\{P_{i}\right\}_{i=1}^{n}$.

It is assumed that every element of the route is a point of food and wine production. A rigorous definition of producer in the mathematical sense will be provided later.

Profit of a producer: the profit function of $j^{\text {th }}$ producer is given by

$$
\pi_{j}\left(q_{j}\right)=p_{j} q_{j}-C_{j}\left(q_{j}\right)
$$

for every quantity $q_{j}$ of goods produced; $p_{j}$ is the unit price which the producer sells the proper good along the route; $C_{j}$ is the production cost function of $j^{\text {th }}$ producer. 
Oligopoly condition. The $p_{j}$ price is fixed in oligopoly mode, however, the price fixed is inferior than the price of the same product on the external market of the Wine Route.

No surpluses assumptions. We suppose that the entire quantity produced $q_{j}$ is sold at a price $p_{j}$. This hypothesis has been used for the construction of profit function $\pi_{j}$.

Technology. It is assumed that the $j^{\text {th }}$ producer has a technology that with a monetary capital $w_{j}$ can obtain

$$
Q_{j}\left(w_{j}\right)=m_{j} w_{j}
$$

unit of output, for every capital invested $w_{j}>0$, with $m_{j}>0$ characteristic technical coefficient of the $j^{\text {th }}$ producer.

Assumption of linear costs. We suppose that the cost function $C_{j}$ is linear, that is

$$
C_{j}\left(q_{j}\right)=\gamma_{j} q_{j}
$$

with $\gamma_{j}$ technical coefficient (marginal cost of producing), for every quantity $q_{j}$.

Proposition (condition of positive profit). The necessary and sufficient condition to obtain positive profits is that the inequality $\gamma_{j}<p_{j}$ holds.

Proof. In fact, we have

$$
\begin{aligned}
\pi_{j}\left(q_{j}\right) & =p_{j} q_{j}-\gamma_{j} q_{j} \\
& =q_{j}\left(p_{j}-\gamma_{j}\right) \\
& =m_{j} w_{j}\left(p_{j}-\gamma_{j}\right)
\end{aligned}
$$

with, $q_{j}=m_{j} w_{j}$.

Definition (of reduced price). The difference between unit price and unit cost, that is the difference

$$
p_{j}^{*}=p_{j}-\gamma_{j}
$$

is called reduced price of $j^{\text {th }}$ producer.

Remark. We have

$$
\pi_{j}\left(m_{j} w_{j}\right)=m_{j} w_{j} p_{j}^{*}
$$

for every capital $w_{j}$ invested by the $j^{\text {th }}$ producer.

Definition. We call multiplier factor of the ${ }^{\text {th }}$ producer the term $u_{j}=m_{j} p_{j}^{*}$. We shall call the term $r_{j}$ $=u_{j}-1$ capitals amplification rate of the $j^{\text {th }}$ producer.

Proposition. The necessary and sufficient condition to obtain a higher capital than the initial one is that multiplier factor $u_{j}=m_{j} p_{j}^{*}$ should be upper than 1 .

Definition (efficiency unless the transport). If the multiplier factor of the ${ }^{\text {th }}$ producer (that is the value $u_{j}=m_{j} p_{j}^{*}$ ) is upper than 1 , we shall call the productive system of the $j^{\text {th }}$ producer efficient unless the transport.

Remark. The term $r_{j}=u_{j}-1$ shall be the amplification rate in a proper sense of the $j{ }^{\text {th }}$ producer capitals if $u_{j}>1$.

Dynamic evolution of the producer profits. We consider 


$$
f_{j}\left(w_{j}\right)=u_{j} w_{j}
$$

for every $w_{j}$ positive. The function $f_{j}$ associates with the amount $w_{j}$ the wealth that ${ }^{\text {th }}$ producer obtains during a producing/selling cycle. At the second producing cycle we obtain

$$
f_{j}\left(u_{j} w\right)=u_{j}\left(u_{j} w_{j}\right)=a^{2} w_{j}
$$

in other terms

$$
f_{j}^{2}(w)=u_{j}^{2} w_{j}
$$

similarly, at the third cycle of production we have

$$
f_{j}\left(u_{j}^{2} w_{j}\right)=u_{j} u_{j}^{2} w_{j}=u_{j}^{3} w_{j}
$$

by induction, at the $n$ cycle of production we will have

$$
f_{j}^{n}(w)=u_{j}^{n} w_{j}
$$

Then the profit growth exponentially with base $u_{j}$ (as we expected).

Remark (on the absence of transport costs). Unlike the case in which the $j^{\text {th }}$ producer sells the goods on distant markets, we must not consider the transport costs $t_{j} q_{j}$ that could diminish the base $u_{j}$, or could dropping it under than 1, with consequent failure of the company (Rodrigue, 2020).

\subsection{Interaction between the various producers}

Fundamental costs hypothesis. We suppose that the costs $c_{j} q_{j}$ supported by the $j{ }^{\text {th }}$ producer for the production of $q_{j}$ units of the good go to finance other producers of the place, re-entering positively in a general economic evaluation of the wine and food route.

Interaction between producers. Considering $c_{i j} q_{i}$ part of the cost of production of the $i^{\text {th }}$ producer that confluences in the coffer of the $j^{\text {th }}$ producer, when $i$ produces $q_{i}=m_{i} w_{i}$; we suppose that the $i^{\text {th }}$ producer, to produce one unit of proper good, should benefit from certain units of goods produced (service supplied) by $j$. The profit of the $j^{\text {th }}$ producer, usually calculable by the function of capital evolution $f_{j}$, we have

$$
f_{j}\left(w_{j}+\sum_{i=1}^{n} c_{i j} q_{i}\right)=u_{j} w_{j}+u_{j} \sum_{i=1}^{n} c_{i j} q_{i}
$$

in other terms, the profit depend on technical-economical term $u_{j}$ and column $c_{(i, j)}$ of matrix of interaction costs $c=\left(c_{i j}\right)_{i, j=1}^{n}$.

Remark (Law of Conservation of the Capital). If we suppose that all the $i^{\text {th }}$ producer costs are realized locally, is valid the law of conservation of the capital

$$
\gamma_{i}=\sum_{j=1} c_{i j}
$$


Conclusion. A Wine Road (or other food and wine route) allowed to use the production costs. If the initial capital of the $j^{\text {th }}$ producer is $w_{j}$, the initial endowment of the road is a vector $w=\left(w_{j}\right)_{j=1}^{n}$, which total capital is $\sum w=\sum_{j=1}^{n} w_{j}$. This total capital, after the first productive cycle become

$$
\begin{aligned}
& f(w)=\sum_{j=1}^{n} f_{j}\left(w_{j}+\sum_{i=1}^{n} c_{i j} q_{i}\right)= \\
& =\sum_{j=1}^{n}\left(u_{j} w_{j}+u_{j} \sum_{i=1}^{n} c_{i j} q_{i}\right)>\sum_{j=1}^{n} u_{j} w_{j}=\langle u, w\rangle
\end{aligned}
$$

with $\langle u, v\rangle$ scalar product of the vector of capitalization factors and $w$ the vector of initial endowment. It can be observed that

$$
\begin{array}{r}
f(w)=\sum_{j=1}^{n} u_{j} w_{j}+\sum_{j=1}^{n} u_{j} \sum_{i=1}^{n} c_{i j} q_{i}= \\
=\langle u, w\rangle+\sum_{i=1}^{n} q_{i} \sum_{J=1}^{n} c_{i j} u_{j}=\langle u, w\rangle+\langle c u, q\rangle,
\end{array}
$$

where the vector obtained from $w$ applying accordingly the matrix $c$ and $q$ is the vector of the quantity produced during the first cycle.

The multiplier of capitals per road cycle is given by the relation

$$
u(S)=\frac{\langle u, w\rangle+\langle c u, q\rangle}{\sum w}
$$

Example: We consider a food and wine route with four producers and the following characteristics:

Producer 1: wine (25 euros per day)

Producer 2: food and handicrafts (25 euros per day)

Producer 3: refreshment (50 euros per day)

Producer 4: accommodation (50 euros per day); and

1. initial endowment $w=(25,25,50,50)$, in euros

2. technology $m=(1,1,2,2)$;

3 . vector of price $p=(4,4,25,50)$;

4. matrix of interaction costs

$$
c=\left(\begin{array}{llll}
0 & 0 & 0 & 1 \\
0 & 0 & 0 & 1 \\
5 & 5 & 0 & 0 \\
1 & 2 & 5 & 0
\end{array}\right) .
$$

We define the wealth of the route obtain after one producing/selling cycle.

First, the vector of unit costs is $\gamma=(1,1,10,8)$, the vector has as components the sum of values on the line of $c$ ), because $\gamma<<p$ the prices were chosen to obtain positive profits of every producers. The vector of reduced price is

$$
p^{*}=p-\gamma=(4,4,25,50)-(1,1,10,8)=(3,3,15,42) .
$$


The vector of capitalization factors is, taking in account the technology vector $m=(1,1,2,2)$.

$$
u=\left(m_{j} p_{j}^{*}\right)_{j=1}^{3}=(3,3,30,84)
$$

The profit due to sales revenue from retail is

$$
\langle u, w\rangle=\langle(3,3,30,84),(25,25,50,50)\rangle=75+75+150+4200=5850 .
$$

The vector of the quantities produced for sale is

$$
q=\left(m_{j} w_{j}\right)_{j=1}^{3}=(25,25,100,100) .
$$

The vector of the capitals generated through a unit production of goods by interaction is

$$
c u=\left(\begin{array}{llll}
0 & 0 & 0 & 1 \\
0 & 0 & 0 & 1 \\
5 & 5 & 0 & 0 \\
1 & 2 & 5 & 0
\end{array}\right)\left(\begin{array}{c}
3 \\
3 \\
30 \\
84
\end{array}\right)=(84,84,30,159)
$$

The profit due to the interaction between producers is

$$
\begin{aligned}
f(w) & =\langle u, w\rangle+(84,84,30,159) q= \\
=5.850 & +27.300=33.150=221 \times 150
\end{aligned}
$$

The multiplier of capital per cycle of the route wine is 221.

The aspects reported above find confirmation, also, in a reworking of Von Tünen model. In fact, in the agricultural space region, Von Tünen identifies the areas with highest income recorded delimiting the space beyond which no longer cultivate it (Rossi \& Tronconi, 2004).

The income is considered as a function of distance, while all other components of the model are considered constant. The income reaches the maximum value to the centre and decreases moving from the center outwards, with the increase of transport costs.

If the traditional model of Von Tünen at the centre of agrarian region there is the city market, assimilating the agrarian region with a territorial administrative region, in this case, the market expands become coincident with the wine road surrounded by various marginal areas cultivated, place of origin of several local products. More recent theory emphasizes optimization of a whole system (wine routes) as something that emerges from simple agents acting on local criteria. In this case, von Thünen's rings emerged through collective actions of the agents. 


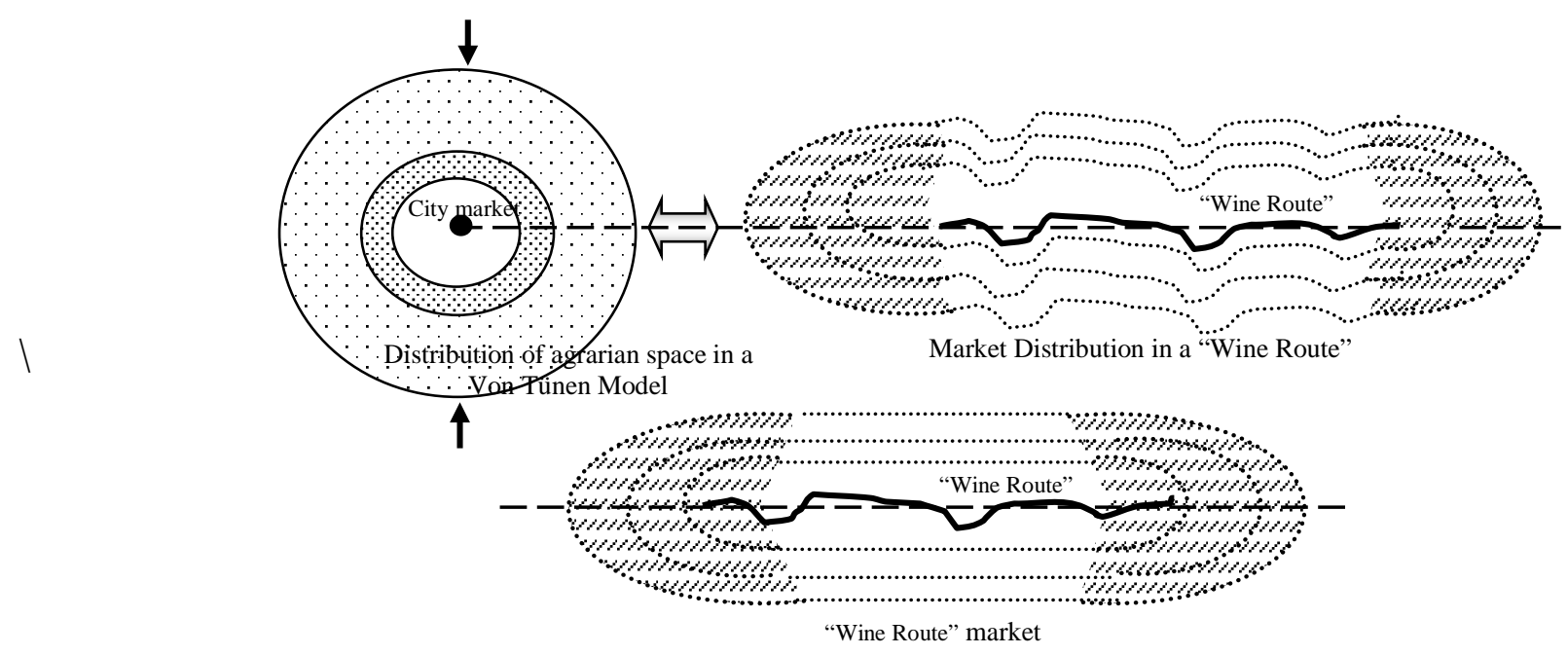

Figure 3. Application of Von Tünen Model to a "Wine Route"

Source: our elaboration

The ring-like structure is thought by many to be the most efficient spatial pattern for an isolated state, but in our case, we deal with a complex interaction with space that can give a power for optimization. Consequently, emerges that the market, expanding its space, will present the marginal areas no longer circular distributed but parallel to the road itself. It specifies that the concentric circles of classical model suffer a crushing towards the wine road cancelling the penalization of the income determined by distance. This model helps us in understanding some of the theoretical connections between individual actions and global behavior in a simplified system, but an utility of this model may be its application in the rural world for wine routes.

\section{SOME CONCLUDING CONSIDERATIONS}

The growing phenomenon of food and wine tourism can represent a source of income for the agricultural companies, both for the ones located in suitable areas in terms of agriculture and tourism, and for those situated in disadvantaged areas and undergoing economic decline and depopulation, where the agricultural and human presidium of territory fulfil to environmental and social functions of public interest.

Tourism and agriculture for a long time have been considered two distinguished and often concurrent worlds in order of using the territory. Nowadays, the process of globalization of economies and trade has modified the structural and organizational setup of agriculture/rural sector transforming it into food system, where it is not only expanded the network of market relations, but also that of services and other territorial activities. Wine roads are instruments through which the wine regions and its products can be disclosed, marketed and enjoyed in the form of tourism.

Wine tourism is starting to become a real network of integrated and coordinated services that allow the tourist to become the "protagonist" of the territory, appreciating and enjoying in-depth and intense its vast potential. In this context and for this purpose all the resources and actors of a territorial reality such as the "Wine Route" (from the cellar to the typical restaurant, from the hotel to the wine producers, from the promotion and information offices to the winemakers, from artisan producer at the local wine shop) must interact with each other, in order to create and offer a final product rich in experiences and cultural, sensorial connotations and relationships with the reference environment. Therefore, the wine roads can represent an opportunity for the development of the rural areas determining an approach of the consumers towards the products and production areas. 
The spatial model described by von Thünen and its application in the development of wine routes can be considered an optimal solution to maximize rural economies and the well-being of the population living there. According to the traditional model of von Thünen, agricultural products move from the production site to the consumer, in the wine routes the consumer is the one who moves to take advantage and enjoy the wine products in the place where they are produced. The Wine Roads represent much more than a valid tool for promoting the product, determining, on the one hand, a process of aggregation and strong collaboration between the offering actors, and on the other constituting an environment to establish a real link with customers-tourists, created by trust and a concrete experience of discovering the cultural, artistic, archaeological and agri-food assets that the roads cross.

Today it is possible to acquire wine directly in the cellar to fight on the one hand the multiplication of prices and on the other to verify personally the quality, authenticity, origin and technologies used for the realization of the product - a unique and inimitable territorial speciality. As, the wine records a significant gap in prices between production and retail sales, today, is marketed by the Italian farms directly overcoming all other products (fruit and vegetables, oil, meat and derivatives, cheese), with a turnover of about one billion euros. The formula of the direct selling of wine, with the possibility to know vineyards and wine cellars, is finding wide spread and the visit to the places of production and wineries, determine an important tourism-economic flow.

The offer of wine tourism is not to be understood simply as a commercial support for wine, but becomes an autonomous tool for the formation of value, favoring sustainable tourism development from an environmental point of view, maintaining the essential qualities and attractions of the territory unaltered and thus avoiding, to damage those resources on which its success most depends. However, the rurality can constitute rents of position and a competitive advantage, that largely

depend on the geographical location and the features of resources. The wine tourism can promote the local development and the smaller wine production (enhancing the local brand) and constitutes a unique opportunity to make companies known directly, by building and disseminating a genuine image and contributing to the creation of a real catchment area.

\section{REFERENCES}

Gori, C. \& Alampi Sottini, V. (2014). The role of the Consortia in the Italian wine production system and the impact of EU and national legislation. Wine Economics and Policy, 3, 62-67. doi:10.1016/j.wep.2014.05.001

Idda, L., Furesi, R. \& Pulina, P. (2002). Agricoltura multifunzionale. In L. Idda (Ed.), Alimentazione e Turismo in Italia, Atti dell’XI Convegno di Studi SIEA (pp. 11-71). Sassari, Italy: Tipografia Editrice G. Gallizzi.

National Association of Wine Producers and Wine Tourism. (n.d.). Designations of Origin of the Wines, Retrieved August 3, 2020, from http://www.assovini.it.

National Observatory on Wine Tourism of the National Association of "Cities of Wine". (2019, February). $15^{\text {th }}$ National Report on Wine Tourism in Italy on The development of wine tourism between the value of the service and expansion of the supply chain. Retrieved August 10, 2020, from file://C:/Users/Utente/Downloads/15-rapporto-turismo-vino-anteprima-bit-milano-2019presentazione_38.pdf

National Observatory on Wine Tourism of the National Association of "Cities of Wine". (2020, May). $16^{\text {th }}$ National Report on Wine Tourism in Italy on Protection, conservation and enhancement of wine tourism as an economic, social and cultural heritage. Retrieved August 12, 2020, from file:///C:/Users/Utente/Downloads/xvi-rapporto-turismo-vino-siena-webinar-27052020_63.pdf

Rodrigue, J. P. (2020). The Geography of Transport Systems, $5^{\text {th }}$ Edition. New York: Routledge.

Rossi, A. \& Tronconi, P. (2004). Il principio di accessibilità. Criticamente. Retrieved July 18, 2020, from http://www.criticamente.com/urbanistica/economia_urbana/Rossi_Andrea-Tronconi_Pierattilio__Appunti_corso_EUT/Rossi_Andrea-Tronconi_Pierattilio___EUT___Principio_di_accessibilita.htm

UniCredit Industry Book 2019 (2019, April 3). The wine sector in Italy: trends, competitive dynamics and growth outlook examined. Retrieved August 7, 2020, from https://www.unicreditgroup.eu/it/pressmedia/news/2019/il-settore-del-vino-in-italia--tendenze--dinamiche-competitive-e.html 